\title{
Effects of Selected Marigold Varieties on Root-knot Nematodes and Tomato and Melon Yields
}

\author{
Antoon T. Ploeg, Department of Nematology, University of California-Riverside, Riverside 92521
}

\begin{abstract}
Ploeg, A. T. 2002. Effect of selected marigold varieties on root-knot nematodes and tomato and melon yields. Plant Dis. 86:505-508.

Field experiments were conducted at two sites in California to evaluate the effects of marigold genotypes Tagetes patula var. Single Gold and Tagetes hybrid var. Polynema on Meloidogyne incognita infestation, root-galling, and yields of tomato grown immediately after marigold. Marigold cultivars were compared with a fallow control and with methyl iodide fumigation of soil prior to cultivation of $M$. incognita-susceptible and $M$. incognita-resistant tomato. Tomato yields after marigold were ca. 50\% higher than after fallow. Marigold Single Gold consistently reduced nematode infestation and galling of tomato roots. Results were not significantly different between methyl iodide fumigation or marigold Single Gold at one site, but methyl iodide outperformed both marigold varieties at the other site. At one site, where melon var. Durango was grown during spring and summer of the year following cultivation of marigolds Single Gold and Polynema, melon yield increases of 95 and $45 \%$, respectively, were still obtained.
\end{abstract}

The root-knot nematode Meloidogyne incognita is widespread and economically important in a range of field and vegetable crops on lighter soil types in southern California (8). Aboveground field symptoms associated with root-knot nematodes are generally nonspecific and may include stunting, chlorosis, wilting under sufficient soil moisture, and increased susceptibility of plants to other diseases (20), ultimately causing reduced yields. Symptoms on host roots infested by root-knot nematodes are usually easily recognizable and consist of galls ranging from pin-point sized $(M$. hapla) to very large, encompassing the entire root system (M. incognita, $M$. javanica, $M$. arenaria). Until recently, growers have relied heavily on nematicides for nematode control. However, costs have increased as a result of federally imposed limitations on nematicide production (M. Lauman, TriCal Biosystems, personal communication), and legislation is restricting the acreage that can be treated annually (1). Consequently, the use of nematicides soon may no longer be an economically viable option, and growers are looking for alternatives.

The cultivation of marigolds (Tagetes spp.) as a rotational crop or in mixed cropping systems for the control of root-knot and lesion (Pratylenchus spp.) nematodes received much attention after reports on the suppression of these nematodes by

Corresponding author: A. T. Ploeg

E-mail: antoon.ploeg@ucr.edu

Accepted for publication 20 December 2001.

Publication no. D-2002-0318-01R

(C) 2002 The American Phytopathological Society marigolds $(11,18,22)$. Biochemical studies have shown that the nematicidal properties of marigolds result from a sequence of chemical reactions in the roots triggered by penetration and movement of the nematodes through the root tissue. The end product of these reactions, a short-lived biotoxic oxygen radical, is thought to kill the nematodes inside the roots (5).

The demand for sustainable and environmentally responsible methods for managing nematodes has re-ignited interest in the use of marigolds $(7,9,14,17,21,23)$. Marigold species most often used for nematode control are T. patula, T. erecta, and $T$. minuta. The rationale for selection of a particular species or variety of marigold is rarely discussed, although the choice of marigold variety may have a significant impact on the level of nematode control (12). Comparative studies have shown that the level of control achieved depends on the marigold genotype and the root-knot nematode species $(10,12,19)$. Thus, for successful incorporation of marigolds into an integrated pest management system, it is important to select a marigold variety that is effective against the locally occurring nematode population(s). In a previous greenhouse study (12), marigold varieties $T$. patula 'Single Gold' and Tagetes hybrid 'Polynema' effectively controlled a local southern California $M$. incognita population on tomato grown after these marigolds. The objective of this study was to evaluate the efficacy of these marigold varieties under field conditions.

\section{MATERIALS AND METHODS}

Field experiment setup. A race $3 \mathrm{M}$. incognita population, originally isolated from cotton in the San Joaquin Valley, CA, was maintained and increased on tomato var. Pixie grown in steam-sterilized sand in a greenhouse $\left(25\right.$ to $32^{\circ} \mathrm{C}$, natural light). The same $M$. incognita population had previously been used in a greenhouse study on the efficacy of marigolds (12). Species and race were identified by isozyme and differential host tests (4). Eggs extracted from the roots of the tomato plants were used to inoculate fields at Irvine (site A) and Reedley (site B), CA. Both fields had loamy-sand soil, were fumigated with methyl bromide prior to inoculation, and were cropped to susceptible hosts (e.g., carrot, sugar beet, okra, beans) for several years to increase $M$. incognita population levels. Experimentation started in the spring of 1998 and 1999 at sites A and B, respectively. In each field, a section comprising six beds ( $76 \mathrm{~cm}$ wide, $47 \mathrm{~m}$ long, $40 \mathrm{~cm}$ between beds) was used. Individual plots consisted of $6.1-\mathrm{m}$-long sections of bed and were separated within beds by 1.5 $\mathrm{m}$, resulting in six plots per bed. Irrigation was through drip-tubing, weeds were removed by hand, and insect control and fertilization were according to standard practices. The following six treatments were applied to the plots on 6 May 1998 (site A) and 27 April 1999 (site B) in a latin-square design with six replicates per treatment: (i) nontreated fallow control; (ii) marigold T. patula var. Single Gold seeded in one row in the center of the bed at $1.5 \mathrm{~g}$ of seed $\mathrm{m}^{-1}$ bed; (iii) marigold Tagetes hybrid var. Polynema seeded in one row in the center of the bed at $1.5 \mathrm{~g}$ of seed $\mathrm{m}^{-1}$ bed; (iv) $M$. incognita-susceptible tomato var. Peto98 planted as 4-week-old transplants at 20 plants per plot; (v) M. incognita-resistant tomato var. Hypeel45 planted as 4-week-old transplants at 20 plants per plot; (vi) methyl iodide applied as a hot-gas fumigation at $112 \mathrm{~kg} \mathrm{ha}^{-1}$ through the drip line under clear 4-mil $(=0.1 \mathrm{~mm}$ thick) polyethylene tarp (6) with the tarp removed 2 weeks after application. On 11 August (site A) and 5 August (site B), tomato and marigolds were cut just above the soil and removed from the field. Seven days later, 4-week-old tomato var. Pixie were transplanted over all plots (20 plants per plot). On 6 November (site A) and 1 November (site B), fruits in each plot were harvested and weighed. The tomato root systems were dug up and taken to the laboratory to evaluate root galling and for nematode analysis. Site A was left fallow over the winter, the beds were reshaped, and the next spring (7 April 1999) melon var. Durango were seeded in all plots (3 seeds at $60-\mathrm{cm}$ distance). After 
emergence, seedlings were thinned to leave one seedling per $60-\mathrm{cm}$ row (10 seedlings per plot). Fruits were harvested weekly in August. At the final harvest (31 August), the melon root systems were dug up and taken to the laboratory to evaluate root galling. Site B was not available to evaluate the treatment effects during the second year.

Nematode analysis. Ten soil cores (5 to $20 \mathrm{~cm}$ deep) were collected from each plot and pooled to one sample per plot. Samples were collected four times: (i) 1 day before applying the treatments (initial first crop and planting the Pixie tomato (final population: Pf); (iii) 1 day before melon planting; and (iv) at the final melon harvest. Nematodes were extracted from two 100-g soil subsamples for each plot, using a modified Baermann-funnel technique (15). Second-stage juveniles (J2) were counted at $\times 40$ magnification, and the counts from the two subsamples were averaged to give a nematode infestation level population: $\mathrm{Pi}$ ); (ii) between harvest of the

per plot. The tomato and melon roots were indexed for galling on a scale from 0 to 10 $(0=$ no galls, $10=100 \%$ galled [2] $)$. An average galling index was calculated for each plot ( $\mathrm{n}=20$ for tomato, $\mathrm{n}=10$ for melon). Total fresh root weight of the tomato plants was determined per plot, roots were then cut into approximately $2 \mathrm{~cm}$ long pieces, J2 were extracted from total root systems for 5 days in a misting chamber (16), and J2 were counted at $\times 40$ magnification.

Treatment effects on $\mathrm{J} 2$ levels $[\log (\mathrm{n}+$ 1) transformed], root galling, and fruit yields were analyzed in an ANOVA procedure, and means were separated with Tukey's range test $(P=0.05)$ using SAS statistical software (SAS Institute, Cary, NC).

\section{RESULTS}

Pretreatment nematode levels (Pi) ranged from 69 to $212 \mathrm{~J} 2$ per $100 \mathrm{~g}$ of soil at site $\mathrm{A}$ and from 20 to $35 \mathrm{~J} 2$ per $100 \mathrm{~g}$ of soil at site $\mathrm{B}$, and were not significantly

Table 1. Effects of marigolds on average $(\mathrm{n}=6)$ soil population levels (per $100 \mathrm{~g}$ soil) and multiplication factors of second stage Meloidogyne incognita juveniles at a field at Irvine, CA (site A)

\begin{tabular}{lccr}
\hline & \multicolumn{3}{c}{ Nematode population level (juveniles per 100 g soil) } \\
\cline { 2 - 4 } Treatment & $\mathbf{P i}^{\mathbf{y}}$ & $\mathbf{P f}^{\mathbf{y}}$ & $\mathbf{P f} / \mathbf{P i}$ \\
\hline Fallow control & $127 \mathrm{a}^{\mathrm{z}}$ & $57 \mathrm{~b}$ & $0.6 \mathrm{~b}$ \\
Tomato 'Peto98' (susceptible) & $81 \mathrm{a}$ & $2,013 \mathrm{a}$ & $113.1 \mathrm{a}$ \\
Tomato 'Hypeel45' (resistant) & $107 \mathrm{a}$ & $7 \mathrm{c}$ & $0.1 \mathrm{~b}$ \\
Methyl iodide fumigation & $212 \mathrm{a}$ & $16 \mathrm{c}$ & $0.1 \mathrm{~b}$ \\
Marigold 'Single Gold' & $69 \mathrm{a}$ & $23 \mathrm{bc}$ & $0.5 \mathrm{~b}$ \\
Marigold 'Polynema' & $188 \mathrm{a}$ & $8 \mathrm{c}$ & $0.1 \mathrm{~b}$ \\
\hline
\end{tabular}

${ }^{\text {y }} \mathrm{Pi}=$ pretreatment population level, $\mathrm{Pf}=$ posttreatment population level.

${ }^{\mathrm{z}}$ Data normalized as $\log (\mathrm{n}+1)$ prior to data analysis. Different letters within a column represent significant differences (Tukey's tests at $P=0.05$ level).

Table 2. Effects of marigolds on average $(\mathrm{n}=6)$ soil population levels (per $100 \mathrm{~g}$ soil) and multiplication factors of second stage Meloidogyne incognita juveniles at a field at Reedley, CA (site B)

\begin{tabular}{lcrc}
\hline & \multicolumn{3}{c}{ Nematode population level (juveniles per 100 g soil) } \\
\cline { 2 - 4 } Treatment & $\mathbf{P i}^{\mathbf{y}}$ & $\mathbf{P f}^{\mathbf{y}}$ & $\mathbf{P f} / \mathbf{P i}$ \\
\hline Fallow control & $23 \mathrm{a}^{\mathrm{z}}$ & $2 \mathrm{c}$ & $0.1 \mathrm{~b}$ \\
Tomato 'Peto98' (susceptible) & $26 \mathrm{a}$ & $216 \mathrm{a}$ & $14.0 \mathrm{a}$ \\
Tomato 'Hypee145' (resistant) & $35 \mathrm{a}$ & $13 \mathrm{~b}$ & $0.8 \mathrm{~b}$ \\
Methyl iodide fumigation & $23 \mathrm{a}$ & $1 \mathrm{c}$ & $0.1 \mathrm{~b}$ \\
Marigold 'Single Gold' & $22 \mathrm{a}$ & $0 \mathrm{c}$ & $0.0 \mathrm{~b}$ \\
Marigold 'Polynema' & $20 \mathrm{a}$ & $1 \mathrm{c}$ & $0.1 \mathrm{~b}$ \\
\hline
\end{tabular}

${ }^{y} \mathrm{Pi}=$ pretreatment population level, $\mathrm{Pf}=$ posttreatment population level.

${ }^{z}$ Data normalized as $\log (n+1)$ prior to data analysis. Different letters within a column represent significant differences (Tukey's tests at $P=0.05$ level).

Table 3. Effects of marigolds on average $(\mathrm{n}=6)$ Meloidogyne incognita root infestation levels $\left(\mathrm{J} 2 \mathrm{~g}^{-1}\right.$ root), root galling (scale 0 to 10) and yield of tomato var. Pixie at a field at Irvine, CA (site A)

\begin{tabular}{|c|c|c|c|}
\hline Treatment & No. of $\mathrm{J}^{2} \mathrm{~g}^{-1}$ root $^{\mathrm{w}}$ & Galling index ${ }^{x}$ & Tomato yield $^{y}$ \\
\hline Fallow control & $653 b^{z}$ & $3.4 \mathrm{~b}$ & $100 \mathrm{~b}$ \\
\hline Tomato 'Peto98' (susceptible) & 3991 a & $6.8 \mathrm{a}$ & $39 \mathrm{c}$ \\
\hline Tomato 'Hypeel45' (resistant) & $646 \mathrm{~b}$ & $2.2 \mathrm{c}$ & $83 \mathrm{bc}$ \\
\hline Methyl iodide fumigation & $68 \mathrm{c}$ & $0.9 \mathrm{~d}$ & $171 \mathrm{a}$ \\
\hline Marigold 'Single Gold' & $61 \mathrm{c}$ & $0.6 \mathrm{~d}$ & $156 \mathrm{a}$ \\
\hline Marigold 'Polynema' & $440 \mathrm{~b}$ & $1.9 \mathrm{c}$ & $151 \mathrm{a}$ \\
\hline
\end{tabular}

${ }^{\mathrm{w}}$ Data normalized as $\log (\mathrm{n}+1)$ prior to data analysis.

${ }^{x}$ Galling according to $(2), 0=$ no galls, $10=100 \%$ of root system galled.

$\mathrm{y}$ Yield as percentage of yield after fallow control.

${ }^{z}$ Different letters within a column represent significant differences (Tukey's tests at $P=0.05$ level). different among treatments at either site (Tables 1 and 2). Posttreatment nematode levels (Pf), however, were significantly different at both sites. As expected, populations were highest after the $M$. incognitasusceptible tomato var. Peto98. Differences between Pf for the other treatments were minor (Tables 1 and 2). Treatments significantly affected yields, root galling, and infestation of tomato Pixie, grown after the treatments over all plots.

At site A (Table 3), very high numbers of $M$. incognita $\mathrm{J} 2$ were extracted from Pixie roots following the susceptible tomato Peto98. Nematode root infestation was not different between fallow, marigold Polynema, or the resistant tomato Hypeel45. Marigold Single Gold, however, reduced the infestation of the following tomato Pixie crop to a level similar to that after methyl iodide fumigation. Treatment effects on the severity of root galling on tomato Pixie largely corresponded with effects on root infestation. Galling was most severe after tomato Peto98, intermediate after fallow, tomato Hypeel45, and marigold Polynema, and minor after marigold Single Gold and methyl iodide fumigation. Compared to the fallow control, Pixie tomato yields were significantly lower after tomato Peto98 and significantly higher after methyl iodide fumigation and after both marigold varieties (Table 3 ).

At site B (Table 4), methyl iodide fumigation and both marigold varieties significantly reduced root-knot nematode infestation and galling, and increased tomato Pixie yields compared with the fallow control. Unlike at site A, methyl iodide fumigation at site $B$ gave significantly better nematode control than both marigold varieties. The $M$. incognita-resistant tomato Hypeel45 did not result in any significant differences compared with the fallow control (Table 4).

On site $\mathrm{A}$, the difference in nematode levels at Pixie tomato harvest persisted over the winter, and at planting of melon var. Durango (ca. 5 months later), soil population levels reflected the root infestation levels and galling of the previous Pixie tomato crop (Tables 3 and 5). At melon harvest, population levels in the soil had increased in all treatments. Populations were highest after fallow, tomato Peto98, and marigold Polynema, intermediate after tomato Hypeel45 and marigold Single Gold, and lowest after methyl iodide treatments. Galling on the melon roots at harvest also still reflected treatment effects from the previous season: severe galling occurred in plots in which tomato Peto98 had been grown, whereas in the methyl iodide and marigold treated plots, galling was still significantly lower than in the fallow control. Finally, a year after their cultivation, both marigold varieties still resulted in a significantly higher melon yield compared with the fallow control (Table 5). 


\section{DISCUSSION}

In this study, the cultivation of selected marigold varieties consistently resulted in a yield increase of ca. $50 \%$ and lowered root-galling of subsequently grown tomato. Previously reported yield increases after cultivation of marigolds in root-knot nematode-infested soil include $38 \%$ in Capsicum pepper (23), 98\% in beans (7), and Single Gold performed as well as methyl iodide fumigation and slightly better than marigold Polynema, with significantly lower root infestation and galling after Single Gold than after Polynema. This corresponds with earlier data (13) that indicated that Polynema allowed some reproduction of $M$. incognita, particularly at high soil temperatures. At site B, the two marigold varieties gave similar results and fumigation. Thus, it appears that at this site, root-knot nematodes reproduced at a faster rate after marigolds than after methyl iodide, or that the marigold effect was restricted to the upper soil layer, allowing reinfestation of tomato roots by nematodes surviving at greater depths.

Fallowing provided measurable but inadequate nematode control compared with methyl iodide fumigation. Growing $M$. incognita-resistant tomato Hypeel45 was comparable to fallow in reducing nematode infestation levels and increasing yields of subsequently grown tomato Pixie. At site A, root infestation and galling of Pixie was not significantly different after tomato Hypeel45 or marigold Polynema. Tomato $34 \%$ in tomato (3). On site A, marigold were less effective than methyl iodide

yields, however, were much higher after marigold Polynema. This suggests that factors other than root-knot nematodes (e.g., other diseases, phytotoxicity) associated with a tomato-tomato cropping sequence were partly responsible for the observed decrease in yield.

There are few data on the persistence of the effect of marigold cultivation on nematode levels, but Reynolds et al. (14) recently reported that one crop cycle of marigold $T$. erecta var. CrackerJack prior to tobacco reduced populations of lesion nematodes (Pratylenchus penetrans) to levels below the economic threshold for more than 2 years. In this study, M. incognita $\mathrm{J} 2$ population levels and melon rootgalling were still significantly lower and melon yields were $45 \%$ higher in plots in which marigold Single Gold had been grown during the previous year compared with plots that had remained fallow.

In conclusion, this study shows that effective control of the root-knot nematode $M$. incognita by selected marigold varieties, as observed in greenhouse experiments (12), also occurred under field conditions. The fact that effective nematode control also resulted in a significant yield increase, and the fact that this yield increase lasted for more than one season, will enhance the potential for marigolds as a viable strategy for nematode management.

\section{ACKNOWLEDGMENTS}

This study was funded by grants from the Division of Agriculture and Natural Resources (DANR), University of California, and the Slosson

Table 4. Effects of marigolds on average $(\mathrm{n}=6)$ Meloidogyne incognita root infestation levels $\left(\mathrm{J} 2 \mathrm{~g}^{-1}\right.$ root), root galling (scale 0 to 10) and yield of tomato var. Pixie at a field at Reedley, CA (site B)

\begin{tabular}{lccc}
\hline Treatment & No. of $\mathbf{J}^{2} \mathbf{~ g}^{\mathbf{- 1}}$ root $^{\mathbf{w}}$ & Galling index $^{\mathbf{x}}$ & Tomato yield $^{\mathbf{y}}$ \\
\hline Fallow control & $305 \mathrm{a}^{\mathrm{z}}$ & $4.8 \mathrm{~b}$ & $100 \mathrm{c}$ \\
Tomato 'Peto98' (susceptible) & $470 \mathrm{a}$ & $8.0 \mathrm{a}$ & $56 \mathrm{~d}$ \\
Tomato 'Hypeel45' (resistant) & $362 \mathrm{a}$ & $5.4 \mathrm{~b}$ & $78 \mathrm{~cd}$ \\
Methyl iodide fumigation & $6 \mathrm{c}$ & $0.1 \mathrm{~d}$ & $237 \mathrm{a}$ \\
Marigold 'Single Gold' & $99 \mathrm{~b}$ & $2.2 \mathrm{c}$ & $155 \mathrm{~b}$ \\
Marigold 'Polynema' & $141 \mathrm{~b}$ & $3.0 \mathrm{c}$ & $140 \mathrm{~b}$ \\
\hline
\end{tabular}

${ }^{\mathrm{w}}$ Data normalized as $\log (\mathrm{n}+1)$ prior to data analysis.

${ }^{x}$ Galling according to $(2), 0=$ no galls, $10=100 \%$ of root system galled.

y Yield as percentage of yield after fallow control.

${ }^{\mathrm{z}}$ Different letters within a column represent significant differences (Tukey's tests at $P=0.05$ level).

Table 5. Effects of marigolds grown during the previous season on average $(\mathrm{n}=6)$ Meloidogyne incognita soil infestation levels (J2 $100 \mathrm{~g} \mathrm{~g}^{-1}$ soil), root galling (scale 0 to 10) and yield of melon var. Durango at a field at Irvine, CA (site A)

\begin{tabular}{lcccc}
\hline & \multicolumn{3}{c}{ Nematode population level (J2 per 100 g soil) } \\
\cline { 2 - 5 } Treatment & Planting $^{\mathbf{w}}$ & Harvest $^{\mathbf{w}}$ & Galling index $^{\mathbf{x}}$ & Melon yield $^{\mathbf{y}}$ \\
\hline Fallow control & $42 \mathrm{~b}^{\mathrm{z}}$ & $371 \mathrm{a}$ & $6.2 \mathrm{~b}$ & $100 \mathrm{~cd}$ \\
Tomato 'Peto98' (susceptible) & $153 \mathrm{a}$ & $289 \mathrm{a}$ & $8.0 \mathrm{a}$ & $90 \mathrm{~d}$ \\
Tomato 'Hypee145' (resistant) & $13 \mathrm{c}$ & $224 \mathrm{~b}$ & $5.4 \mathrm{~b}$ & $112 \mathrm{~cd}$ \\
Methyl iodide fumigation & $2 \mathrm{~d}$ & $190 \mathrm{c}$ & $1.6 \mathrm{e}$ & $126 \mathrm{bc}$ \\
Marigold 'Single Gold' & $2 \mathrm{~d}$ & $256 \mathrm{~b}$ & $3.4 \mathrm{~d}$ & $195 \mathrm{a}$ \\
Marigold 'Polynema' & $23 \mathrm{c}$ & $311 \mathrm{a}$ & $4.5 \mathrm{c}$ & $145 \mathrm{~b}$ \\
\hline
\end{tabular}

${ }^{\mathrm{w}}$ Data normalized as $\log (\mathrm{n}+1)$ prior to data analysis.

${ }^{x}$ Galling according to $(2), 0=$ no galls, $10=100 \%$ of root system galled.

$\mathrm{y}$ Yield as percentage of yield after fallow control.

${ }^{z}$ Different letters within a column represent significant differences (Tukey's tests at $P=0.05$ level).
Foundation. The author thanks Sahin Seeds, The Netherlands, for providing seed of marigold Single Gold and S. Edwards and C. Caldwell for their technical assistance.

\section{LITERATURE CITED}

1. Anonymous. 2001. California Department of Pesticide Regulation. Telone (1,3-D) County Permit Conditions for 2001.

2. Bridge, J., and Page, S. L. J. 1980. Estimation of root-knot nematode infestation levels on roots using a rating chart. Trop. Pest Manag. 26:296-298.

3. Bünte, R., and Müller, J. 1996. Einfluß Ölrettich-Genotypen auf die Abundanzdynamik von Meloidogyne hapla und M. incognita. Z. Pflanzenkrankh. Pflanzenschutz 103:527-534.

4. Eisenback, J. D., and Triantaphyllou, H. H 1991. Root-knot nematodes: Meloidogyne species and races. Pages 191-274 in: Manual of Agricultural Nematology. W. R. Nickle, ed. Marcel Dekker, New York.

5. Gommers, F. J., and Bakker, J. 1988. Physiological changes induced by plant responses or products. Pages 3-22 in: Diseases of Nematodes. G. O. Poinar, Jr., and H. B. Jansson, eds. CRC Press, Boca Raton, FL.

6. Hutchinson, C. M., McGiffin, M. E., Ohr, H. D., Sims, J. J., and Becker, J. O. 1999. Evaluation of methyl iodide as a soil fumigant for root-knot nematode control in carrot production. Plant Dis. 83:33-36.

7. Ijani, A. S. M., Mabagala, R. B., and Nchimbi-Msolla, S. 2000. Efficacy of different control methods applied separately and in combination in managing root-knot nematodes (Meloidogyne spp.) in common beans. Eur. J. Plant Pathol. 106:1-10.

8. Koenning, S. R., Overstreet, C., Noling, J. W., Donald, P. A., Becker, J. O., and Fortnum, B. A. 1999. Survey of crop losses in response to phytoparasitic nematodes in the United States for 1994. J. Nematol. 31(4S):587-618

9. McSorley, R., Ozores-Hampton, M., Stansly, P. A., and Conner, J. M. 1999. Nematode management, soil fertility, and yield in organic vegetable production. Nematropica 29:205-213.

10. Motsinger, R. E., Moody, E. H., and Gay, C. M. 1977. Reaction of certain French marigold (Tagetes patula) cultivars to three Meloidogyne species. J. Nematol. 31:62-69.

11. Oostenbrink, M., s'Jacob, J. J., and Kuiper, K. 1957. Tagetes als Feindpflanzen von Pratylenchus-Arten. Nematol. Suppl. 2:424S-433S.

12. Ploeg, A. T. 1999. Greenhouse studies on the effect of marigolds (Tagetes spp.) on four Meloidogyne species. J. Nematol. 31:62-69.

13. Ploeg, A. T., and Maris, P. C. 1999. Effects of temperature on the duration of the life cycle of a Meloidogyne incognita population. Nematology 1:389-393.

14. Reynolds, B. L., Potter, J. W., and BallCoelho, B. R. 2000. Crop rotation with Tagetes sp. is an alternative to chemical fumigation for control of root-lesion nematodes. Agron. J. 92:957-966.

15. Rodriguez-Kabana, R., and Pope, M. H. 1981. A simple incubation method for the extraction of nematodes from soil. Nematropica 11:175185.

16. Seinhorst, J. W. 1950. De betekenis van de toestand van de grond voor het optreden vazn de aantasting door het stengelaaltje (Ditylenchus dipsaci (Kühn) Filipjev). Tijdschr. Plantenziekten 56:289-348.

17. Sellami, S., and Cheifa, H. 1997. Effect of Tagetes erecta on Meloidogyne in a greenhouse. Meded. Fac. Landb. en Toegepaste Biol. Wetensch. Univ. Gent 62:737-740.

18. Steiner, G. 1941. Nematodes parasitic on and associated with roots of marigolds (Tagetes hybrids). Proc. Biol. Soc. Washington 
$54: 31-34$.

19. Suatmadji, R. W. 1969. Studies on the effect of Tagetes species on plant-parasitic nematodes. Wageningen, The Netherlands. $\mathrm{H}$. Veenman en Zonen.

20. Taylor, A. L., and Sasser, J. N. 1978. Biology, identification and control of root-knot nematodes. North Carolina State University
Graphics.

21. Topp, E., Millar, S., Bork, H., and Welsh, M. 1998. Effects of marigold (Tagetes sp.) roots on soil microorgansims. Biol. Fertility Soils 27:149-154.

22. Tyler, J. 1938. Proceedings of the root-knot nematode conference held at Atlanta, Georgia, February 4, 1938. Plant Dis. Rep. Suppl.
109:133-151.

23. Zavaleta-Mejia, E., Castro, A. E., and Zamudio, V. 1993. Effect of cropping and incorporation of crop residues of Tagetes erecta $\mathrm{L}$. on the population development of Meloidogyne incognita (Kofoid and White) Chitwood on pepper (Capsicum annuum L.). Nematropica 23:49-56. 